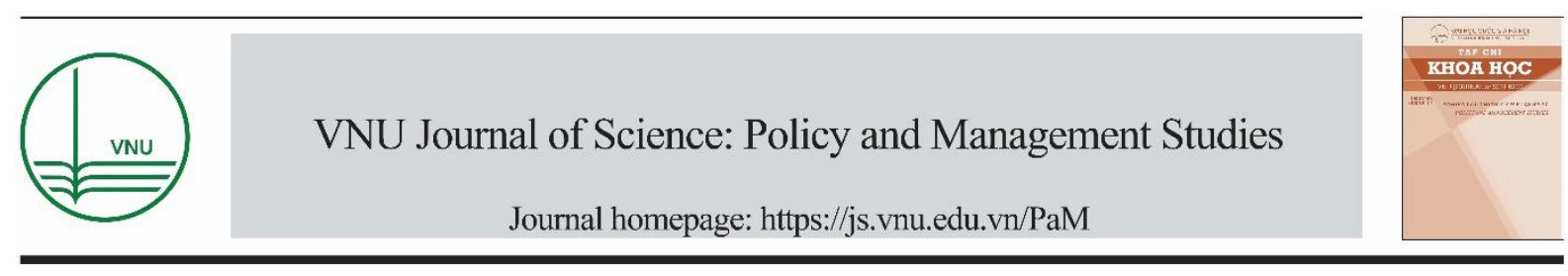

\title{
Analysis of Access and Equity in the Vietnamese Higher Education System
}

\author{
Vu Hoang Linh ${ }^{1, *}$, Nguyen Thuy Anh ${ }^{2}$ \\ ${ }^{1}$ VNU Vietnam - Japan University, Luи Huи Phuoc, Nam Tu Liem, Hanoi, Vietnam \\ ${ }^{2}$ VNU University of Economics and Business, 144 Xuan Thuy, Cau Giay, Hanoi, Vietnam
}

Received 06 December 2018

Revised 20 December 2018; Accepted 22 December 2018

\begin{abstract}
The Vietnamese higher education system has expanded rapidly during the past two decades. Yet, the equity in terms of access to higher education in the country is understudied. This paper is an attempt to look at the current Vietnam's higher education system in terms of access and equity. Using logistic regression model and data from the 2016 Vietnam Household Living Standard Survey, the paper examines the factors explaining the enrolment in Vietnam's higher education. The study result shows that there has been a wide gap in the access between the rich and the poor, and between the Kinh/Hoa majority and the ethnic minority group in Vietnam. Therefore, there is a strong need of public policies to assist disadvantaged groups in getting access to higher education.
\end{abstract}

Keywords: Higher education, access, equity.

\section{Introduction}

Higher education brings about important private and public benefits, and is essential to the development of a country's high-skill workforce for global competition. Private economic benefits of higher education include higher salaries, better employment opportunities, increased savings, and upward mobility. An individual with higher education also obtains non-economic benefits such as a

\footnotetext{
${ }^{*}$ Corresponding author. Tel.: 84-906691976.

Email: vhlinh76@gmail.com

https://doi.org/10.25073/2588-1116/vnupam.4163
}

better quality of life, improved health, and greater opportunities for the future. Higher education can also be linked to the demand for high quality skills in the new knowledge economy. Higher education, through the creation of new knowledge, development of innovative technologies and development of scholars in varied specialties, can bolster the labor force in today's global and competitive economy.

While higher education attainment results in extensive social and private benefits, access and inclusion are essential for achieving social justice, and ensuring the realization of the full potential of all young people. First, in the 
interest of fairness, every individual must be given an equal chance to partake in higher education and enjoy its benefits, irrespective of income and other social characteristics including gender, ethnicity, and language. Second, there is a strong efficiency argument in favor of equity promotion. A talented but lowincome student who is denied entry into higher education represents a loss of human capital for society. The lack of opportunities for access and success in higher education will lead to underdeveloped or undeveloped human resources. Gender inequality in higher education also is also a hindrance to development and persists in many parts of the developing world, particularly in the countries of the Middle East, Sub-Saharan Africa and South Asia.

Even in the few countries where gender parity has been achieved in higher education, "gender streaming" of women toward specific types of non-university institutions and/or toward specific disciplines leading to lowpaying occupations can be observed. Female over-representation persists in teaching institutes, nursing schools, and secretarial schools. Women are commonly overrepresented in the humanities, while most often underrepresented in subjects such as agriculture, medicine, business, science and engineering programs. Women are also underrepresented in leadership roles in higher education institutions.

Barriers to higher education enrolment can be streamed into non-monetary and monetary ones. Academic ability, information access, motivation, inflexibility of university admission processes, family environment and other forms of cultural capital are some of the non-monetary reasons that have been recognized as important factors in explaining poor participation of lowincome individuals in higher education. Monetary barriers to higher education include the cost-benefit barrier, the cash-constraint or liquidity barrier, and the internalized liquidity constraint or the debt aversion barrier. The costbenefit barrier occurs when an individual decides that the costs of attending university (including tuition and living expenses as well as opportunity costs of not working during the duration of the course) outweigh the returns to their education. Liquidity barriers refer to a student's inability to gather the necessary resources to pursue higher education after having decided that the benefits do outweigh the costs. And, the debt aversion constraint occurs when a student values the benefits of higher education over its costs, can borrow to obtain access to sufficient financial resources, but, regardless of these factors, chooses not to matriculate because the financial resources available to him/her include loans. All three of these monetary barriers are contributing to rising inequity in higher education participation.

The objective of this paper is to analyze the current situation of Vietnam in terms of access and equity in higher education opportunities, and investigate the driven factors for higher education enrolment in Vietnam. In the following section, the paper provides a brief overview of the education system in Vietnam. Section 3 reviews the current literature on access and equity to higher education. Section 4 analyzes disparities in access, equity and expenditure in higher education. This is followed by the econometric model in Section 5 to flesh out the determinants of disparities. Finally, the paper provides some concluding remarks and policy implications to promote access and equity in Vietnam's higher education.

\section{Current higher education system in Vietnam}

The current education system in Vietnam has five levels: pre-primary education; primary education; lower secondary education; upper secondary education; and higher (tertiary) education. The higher education (HE) system includes university (from 4 to 6 years, depending on the field of study), college (3 
years), master (from 1 to 3 years after getting university degree, depending on the field of education and the forms of study) and doctorate education ( 2 to 4 years after getting master degree).

Table 1 summarizes major indicators of the higher education system in Vietnam. There has been a fast growth rate in the system during the
2005- 2010 period, in which both the number of institutions and the enrollment increase by 50percent. This could be caused by the Government's deliberate effort to expand the higher education system during that period. Yet, during the most recent period (2011-2015), the number of institutions as well as students remained stable.

Table 1. Basic indicators of the higher education system in Vietnam.

\begin{tabular}{lllllllll}
\hline & 2000 & 2005 & 2010 & 2011 & 2012 & 2013 & 2014 & 2015 \\
\hline Number of Institutions & 178 & 277 & 414 & 419 & 421 & 428 & 436 & 445 \\
Public & 148 & 243 & 334 & 337 & 340 & 343 & 347 & 357 \\
Non-public & 30 & 34 & 80 & 82 & 81 & 85 & 89 & 88 \\
$\begin{array}{l}\text { Number of teachers } \\
\text { (thousand) }\end{array}$ & 32.3 & 48.6 & 74.6 & 84.1 & 87.7 & 91.6 & 91.4 & 93.5 \\
Public & 27.9 & 42 & 63.3 & 70.4 & 73.9 & 75.2 & 74.1 & 76.1 \\
Non-public & 4.5 & 6.6 & 11.3 & 13.7 & 13.8 & 16.4 & 17.3 & 17.4 \\
Male &.. & 28.1 & 39.2 & 43 & 44.9 & 46.7 & 42.3 & 43.3 \\
Female &.. & 20.5 & 35.4 & 41.1 & 42.8 & 44.9 & 49.1 & 50.2 \\
$\begin{array}{l}\text { Number of students } \\
\text { (thousand) }\end{array}$ & & & & & & & & \\
Public & 899.5 & 1387.1 & 2162.1 & 2208.1 & 2178.6 & 2061.6 & 2363.9 & 2118.5 \\
Non-public & 795.6 & 1226.7 & 1828.2 & 1873.1 & 1855.2 & 1792 & 2050.3 & 1847.1 \\
Male & 103.9 & 160.4 & 333.9 & 335 & 323.4 & 269.6 & 313.6 & 271.4 \\
Female &.. & 714.5 & 1.082 .6 & 1.105 .6 & 1.090 .8 & 1.015 .8 & 1.116 .4 & 1.033 .9 \\
$\begin{array}{l}\text { Number of graduates } \\
\text { (thousand) }\end{array}$ &.. & 672.6 & 1.079 .5 & 1.102 .5 & 1.087 .8 & 1.045 .8 & 1.247 .5 & 1.084 .6 \\
Public & 162.5 & 210.9 & 318.4 & 398.2 & 425.2 & 406.3 & 441.8 & 353.6 \\
Non-public & 149.9 & 195 & 278.3 & 334.5 & 357.2 & 350.6 & 377.9 & 308.7 \\
\hline
\end{tabular}

Source: General Statistics Office, Statistical Yearbook, various years.

In 2016, there was a total of 442 higher education institutions (HEIs) in Vietnam (MOET, 2017). Of the 442 institutions, 219 are universities and 223 colleges. Private institutions account for 29 percent of total HEIs in Vietnam, including 60 universities and 30 colleges (Table 2). Although the government policy has motivated educational socialization, thus providing a strong incentive to increase the number of private HEIs, share of their enrolment is still low, accounting for only 20 percent of the number of HEIs and 13 percent of total tertiary enrolment in 2016.
Vietnam's gross enrollment rate for higher education rapidly increased over the last 15 years, from 9.4 percent in 2000 to 30.5 percent in 2014, but then reduced to 28.8percent in 2015. However, Vietnam still has a comparatively low higher education coverage, compared to countries in the region (Table 3 ). Not only the number of spaces available, but also is student choice of study programs largely limited, with little responsiveness to labor market needs. In 2013, 2.6 million students completed high school, of which 1.7 million took the national entrance examination to 
compete for university and college places. In total, 616,400 admission places were offered, of which only 498,700 places (or 30 percent of the total candidates) were filled [1].
Table 3 compares the gross enrollment rate at the higher education level between Vietnam and other countries in the region.

Table 2. Number of institutions and total enrolment classified by type

\begin{tabular}{lllll}
\hline & 2013 & & 2016 & \\
& Number of institutions & Total enrollment & Number of institutions & $\begin{array}{l}\text { Total } \\
\text { enrollment }\end{array}$ \\
\hline Colleges & 214 & 724,232 & 219 & 449,558 \\
Private Colleges & 29 & 135,193 & 30 & 57,533 \\
Public Colleges & 185 & 589,039 & 189 & 392,025 \\
Universities & 207 & $1,453,067$ & 223 & $1,753,174$ \\
Private Universities & 54 & 177,459 & 60 & 232,367 \\
Public Universities & 153 & $1,275,608$ & 163 & $1,520,807$ \\
\hline Overall Total & 421 & $2,177,299$ & 442 & $2,202,732$
\end{tabular}

Source: MOET Statistics, MOET website http://www.moet.gov.vn/thong-ke/Pages/thong-ko-giao-duc-daihoc.aspx?ItemID $=5137$ retrieved on November $1^{\text {st }}, 2018$.

Note: There could be some minor differences among the education statistics from MOET, GSO and the international database by the World Bank and UNESCO.

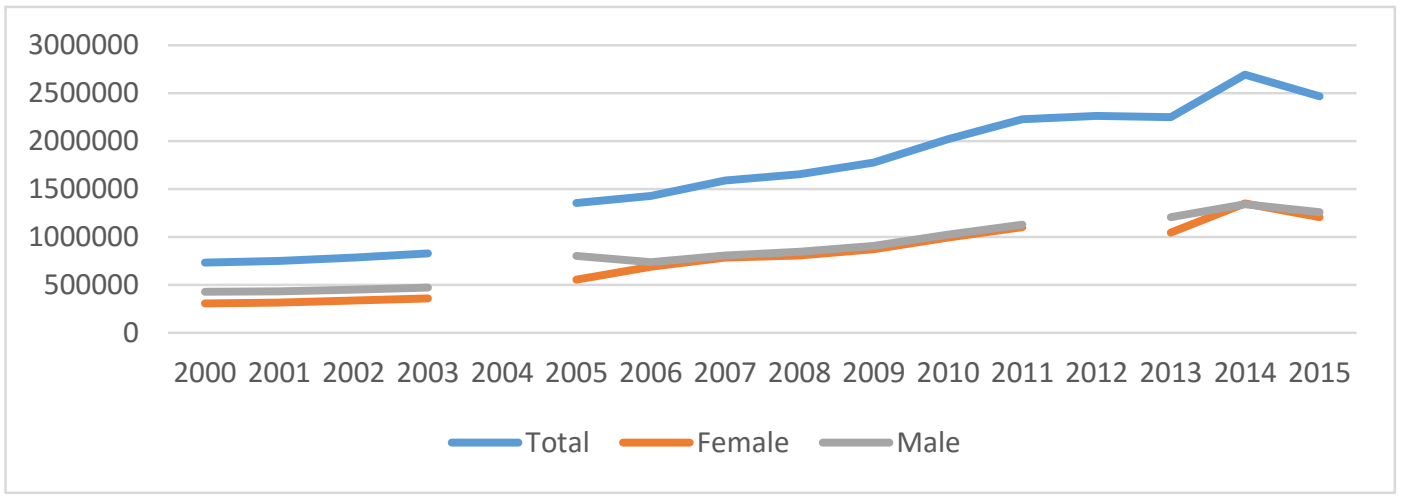

Figure 1. Enrolment in Vietnam's higher education

Source: World Bank Education Statistics, data unreported in 2004 and partly in 2012

Table 3. Gross enrollment rate for higher education, comparison among countries in the region

\begin{tabular}{llllllllll}
\hline & 2000 & 2005 & 2010 & 2011 & 2012 & 2013 & 2014 & 2015 & 2016 \\
\hline Myanmar &.. &.. &.. & 14.5 & 13.9 &.. &.. &.. &.. \\
Cambodia & 2.5 & 3.4 & 14.1 & 16.0 &.. &.. &.. & 13.1 &.. \\
Lao PDR & 2.7 & 7.8 & 16.6 & 17.8 & 17.6 & 19.0 & 18.3 & 18.1 & 17.2 \\
Brunei Darussalam & 12.7 & 14.8 & 15.5 & 17.4 & 22.4 & 24.2 & 31.7 & 30.8 & 30.9 \\
Indonesia & 14.9 & 17.3 & 23.0 & 24.8 & 28.7 & 29.5 & 29.6 & 23.3 & 27.9 \\
China & 7.7 & 19.3 & 24.1 & 25.3 & 28.0 & 31.5 & 41.3 & 45.4 & 48.4 \\
\hline
\end{tabular}




\begin{tabular}{llllllllll}
\hline Philippines &. & 27.5 & 29.6 & 30.8 & 31.2 & 33.5 & 35.6 &.. &.. \\
Malaysia & 25.7 & 27.9 &.. &.. &. &. & 36.9 & 42.4 & 44.1 \\
Thailand & 34.9 & 44.2 & 50.4 & 52.3 & 50.7 & 49.8 & 50.2 & 45.9 &.. \\
Mongolia & 30.2 & 44.7 & 53.8 & 55.7 & 58.7 & 62.2 & 64.3 & 68.6 & 64.6 \\
Japan & 48.7 & 55.0 & 58.1 & 60.1 & 61.4 & 62.1 & 62.9 & 63.2 &.. \\
Korea, Rep. & 78.4 & 90.3 & 102.8 & 100.5 & 96.6 & 94.4 & 93.4 & 93.3 &.. \\
Vietnam & 9.4 & 16.1 & 22.7 & 24.8 & 25.0 & 25.0 & 30.4 & 28.8 & 28.3 \\
Lower middle income & 11.3 & 13.2 & 18.2 & 20.7 & 21.9 & 22.0 & 23.1 & 23.1 &.. \\
Middle income & 14.1 & 19.6 & 25.2 & 27.1 & 28.5 & 29.5 & 32.4 & 33.3 &.. \\
East Asia \& Pacific & 15.5 & 23.3 & 27.8 & 29.0 & 31.1 & 33.3 & 39.1 &.. &.. \\
World & 19.0 & 24.3 & 29.3 & 31.1 & 32.2 & 32.8 & 35.0 & 35.7 &.. \\
\hline
\end{tabular}

Source: World Bank Education Statistics, http://datatopics.worldbank.org/education/

\section{Previous studies on equity of and access to higher education in Vietnam}

This topic has not been well examined in Vietnam. Linh et. al. [2] is the only study focusing on the issue of accessibility and affordability of tertiary education. The authors used national survey data from 2006 to calculate accessibility indices to tertiary education in Vietnam and compare with similar indices in other countries. They found that while the access to tertiary education has been expanding steadily, many groups of people in Vietnam, particularly ethnic minority and lowincome groups, have been unable to catch up with the expanding access. While this study is quite interesting, it was quite outdated now. Hayden and Ly [3] use available secondary statistics to state that "in the limited evidence available, however, it appears that these opportunities have not been distributed equitably. Young people from better-off homes from urban areas and from the ethnic majority group seem more likely to have benefitted. Girls also appear to have benefitted, a trend that is a reverse of the past".

World Bank [4] concludes that, despite an impressive growth of the HE system, the GER in Vietnam is still lower than that of other performing countries, i.e. China, Malaysia, the Philippines, and Thailand. In addition, the estimation of completion and enrolment rates of higher education by area (urban and rural), income quintiles (the richest and the poorest), and gender (males and females) suggests that the HE completion rates are quite different between these groups of people. However, the causes of the said disparities have not been carefully examined. The study suggests that there are some specific barriers that may be limiting individual's access to HE. These obstacles include a limited number of universities and faculties, financial barriers, and familial characteristics.

In his review of higher education system in Vietnam, Ngo [5] states that access to higher education for young people from rural, remote and mountainous areas and children of underprivileged families has increased by about 70 percent annually. He attributes this widening access to the government policies, including the establishment and development of public and non-public higher education institutions, especially those in remote areas; the introduction of a student loan programmed; and the expansion of "in-service" higher education. However, his study does not provide in-depth analysis on the access to higher education and its determinants.

This study therefore would provide more concrete and systematic results on the current access and equity of tertiary education system, as well as examining the factors that influence higher education access and completion in Vietnam. 


\section{Access, equity and financing in higher education in Vietnam}

Some indicators can be calculated to measure the access to higher education system (see $[2,6,7]$ ). In this section, we use the following two indicators:

- Gross Enrolment Ratio (GER): is calculated by expressing the number of students enrolling in higher education, regardless of age, as a percentage of the population of a certain age group. In this paper, that age group is defined as the age ranging from 18 to 22 , which is of the five-year age group after the high school leaving age.

- Education Attainment Ratio (EAR): is measured as a percentage of population that attains a particular educational level. We calculate the ratio between the people older than 25 who have completed college or university education in relation to the total population in the same age range.

Some indicators that can be calculated to measure the equity of higher education system. Firstly, Gender Parity Index (GPI) can be calculated. GPI is defined as the ratio of GER of female students enrolled at a given level of education to GER of male students at the same level [6]. A value of less than one indicates differences in favor of males, whereas a value near one indicates that parity has been more or less achieved. Proximity to gender parity is another possible indicator of equity in higher education access. In this indicator, any deviation from gender parity is treated as being indicative of inequality and, therefore, negative. Secondly, inequality in the access to higher education between different groups can be examined by obtaining the differences in the GER of the different groups (by income, ethnicity and urban/rural).

Vietnam has achieved significant improvements in the access to higher education during the last 10 years, in terms of gross and net enrollment rate, participation ratio and education attainment. Yet, more achievement has been obtained in the urban areas and among richer population than in rural areas and among the poor population.

Figure $2 a, 2 b$ and $2 c$ show the gap in GER in terms of gender, urban/rural and ethnic groups. Females have higher GER than males at the higher education level and the gap seems increased in 2016. The gap in GER between urban and rural areas has been quite stable. Meanwhile, ethnic minorities continue to lag far behind the Kinh/Hoa group in terms of access to higher education.

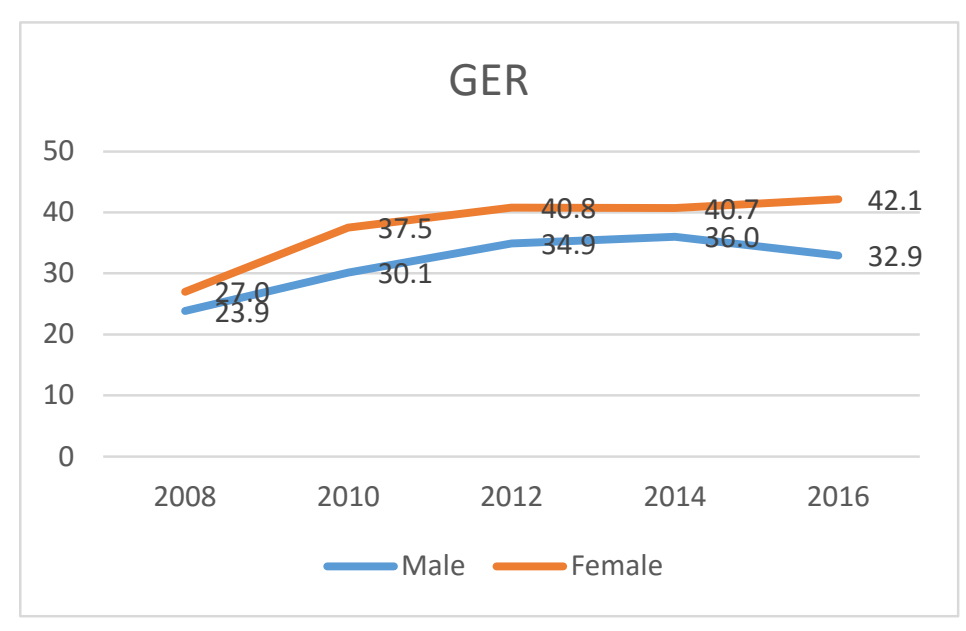

Figure 2a. Gap in GER between females and males. 


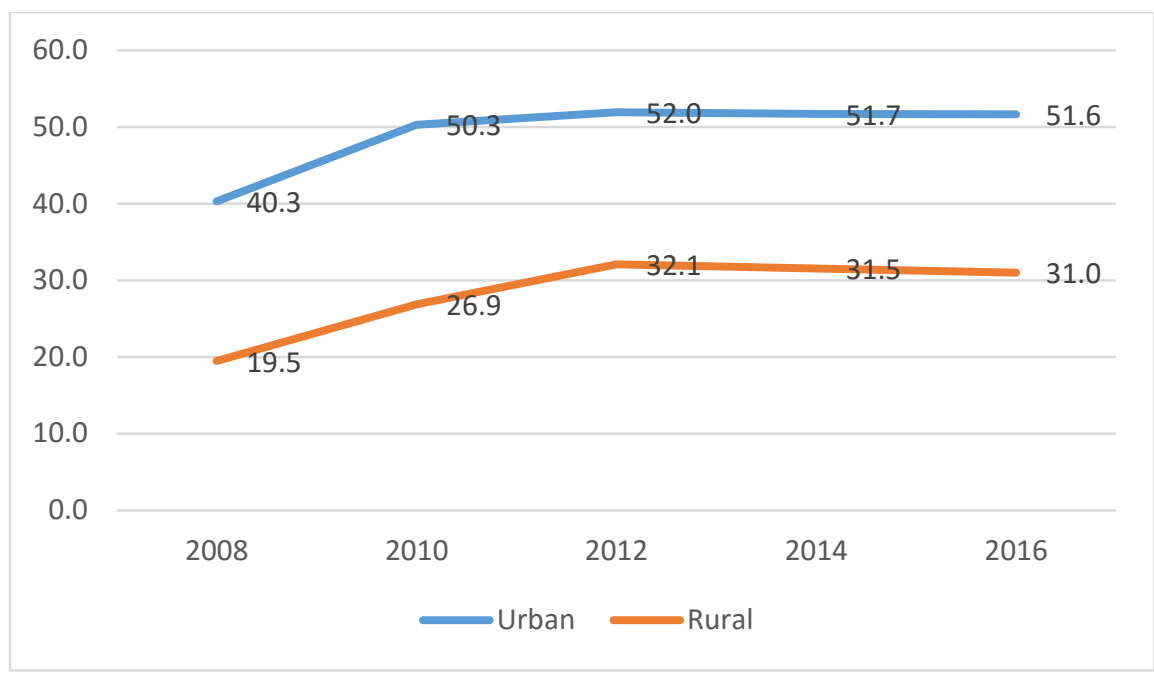

Figure 2b. Gap in GER between urban and rural areas.

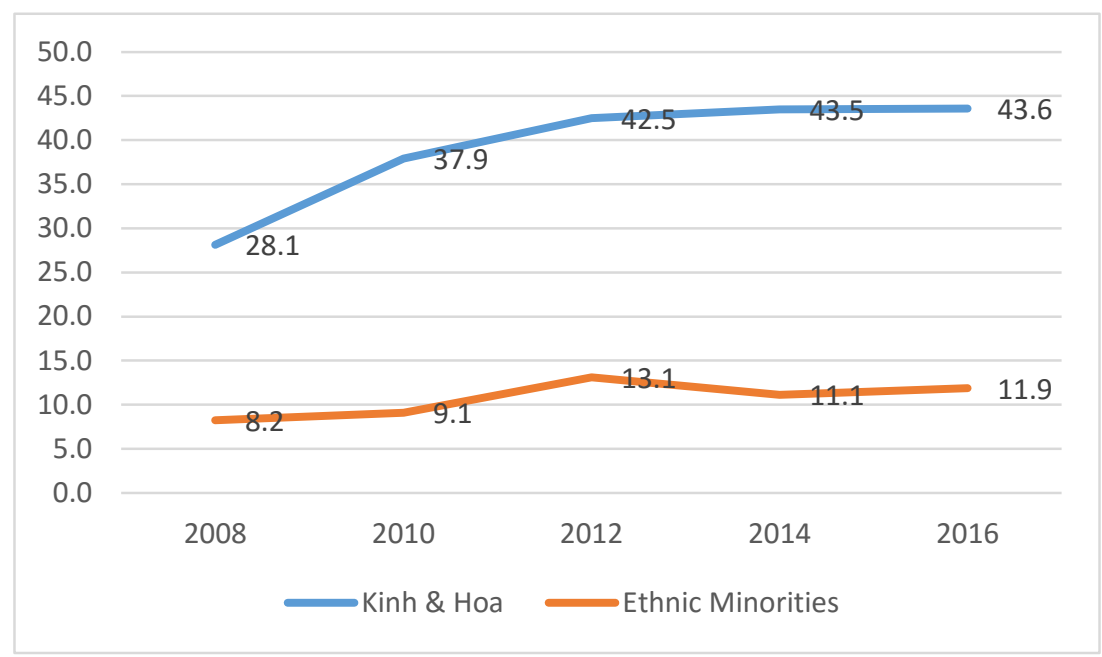

Figure 2c. Gap in GER between Kinh/Hoa and ethnic minorities.

Table 4 indicates a big gap between expenditure quintiles in terms of GERs and Education Attainment. In 2016, only 5.6 percent of the 18-22 age group in the bottom quintile were enrolled in higher education while the corresponding figure for the top quintile was 66 percent. Less than 1 percent of all people aged $25+$ in the bottom quintile have a university or college degree while 28 percent of the top quintile have.
Table 5 summarizes the contributions to education by the Government and households. In total, higher education expenditure accounts for 25.8 percent of total expenditure for education in 2013. It is notable that in most other countries, the spending for higher education is often higher than for vocational education but this is not the case in Vietnam. As for the sources of contribution, households spending contributes about 45 percent of total expenditure. It is much higher than the household share at other levels of education. 
Table 4. Gap in GER and education achievement among expenditure quintiles

\begin{tabular}{llllll}
\hline & 2008 & 2010 & 2012 & 2014 & 2016 \\
\hline GER & & & & & \\
Quintile 1 & 2.5 & 4.2 & 6.2 & 5.6 & 5.6 \\
Quintile 2 & 8.2 & 17.1 & 18.7 & 20.1 & 15.4 \\
Quintile 3 & 20.4 & 28.9 & 32.2 & 34.0 & 32.9 \\
Quintile 4 & 32.4 & 41.5 & 49.9 & 49.0 & 48.4 \\
Quintile 5 & 52.8 & 62.0 & 64.5 & 70.2 & 66.4 \\
\hline Education Attainment & & & & & \\
\hline Quintile 1 & 0.2 & 0.4 & 0.5 & 0.6 & 0.7 \\
Quintile 2 & 0.7 & 0.8 & 1.5 & 2.7 & 2.7 \\
Quintile 3 & 1.9 & 2.9 & 3.6 & 5.1 & 5.0 \\
Quintile 4 & 5.4 & 8.2 & 8.5 & 11.1 & 11.2 \\
Quintile 5 & 20.1 & 25.1 & 25.6 & 28.9 & 27.5
\end{tabular}

Table 5. Expenditure by level of education and source of funding, 2013, by total expenditure for education

\begin{tabular}{lllll}
\hline & $\begin{array}{l}\text { Government } \\
\text { expenditure }\end{array}$ & $\begin{array}{l}\text { Household } \\
\text { expenditure }\end{array}$ & $\begin{array}{l}\text { Total } \\
\text { expenditure }\end{array}$ & $\begin{array}{l}\text { Household } \\
\text { share } \\
\text { (percent) }\end{array}$ \\
\hline Higher education & 14.1 & 11.7 & 25.8 & 45.4 \\
Vocational education & 18.6 & 8.9 & 27.5 & 32.4 \\
Upper secondary & 8.5 & 3.7 & 12.2 & 30.3 \\
Lower secondary & 9.8 & 1.9 & 11.7 & 16.2 \\
Primary & 8.3 & 1.2 & 9.5 & 12.6 \\
Pre-primary & 7.6 & 2.1 & 9.7 & 21.7 \\
& \multicolumn{5}{c}{ Source: GoV (2016) }
\end{tabular}

Figure 3 examines the evolution of household spending for education in recent years. Household expenditure for higher education and vocational education cost significantly higher than general education, with a marked increase for higher education in 2016. In 2016, for example, an average household spends 19.5 million VND for higher education, while the average spending for high school education is only 5.6 million VND. This rise in higher education spending may further widen the gap in access between the rich and the poor in the society and dampen the access to higher education.

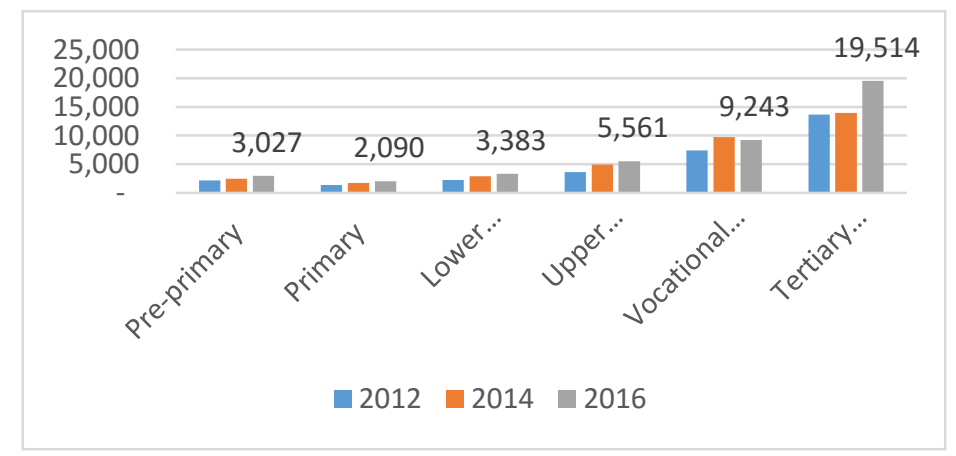

Figure 3. Household average expenditure per student, by level of education, 2012, 2014 and 2016 (thousand VND) 
To examine the gap in terms of household spending, figure 4 shows the inequality among socioeconomic groups. Spending for male students is higher than female. Similarly, mean spending per a Kinh/Hoa student is more than an ethnic minority person. Most remarkable is the difference between quintile 5 (the richest 20percent of the population) with quintile 1 . The average spending for higher education in a household in quintile 5 is more than three times that in the first quintile household.

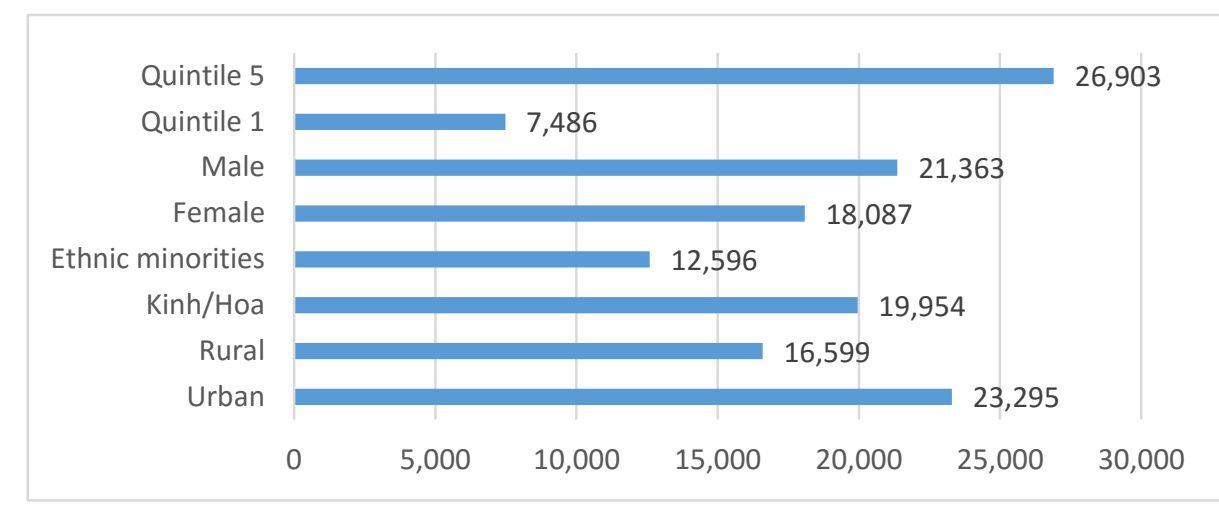

Figure 4. Household spending per higher education, 2016 (in thousand VND).

Source: Author's calculation using VHLSS 2016.

\section{Factors determining access to higher education}

In order to determine the factors affecting access to higher education, we first use a logistic regression model that is applied to binary variable ([8]. The model is as follows:

$$
P\left(y_{i, j}=1 \mid X\right)=F\left(\beta_{0}+I_{i, j} \beta_{1}+H_{j} \beta_{2}\right)(1)
$$

Where $y_{i, j}$ is a dummy variable reflecting higher education attendance of individual $i$ from household $j . I_{i, j}$ is the vector of individual characteristics and $H_{j}$ is the vector of household characteristics.
The logistic function is as follows: $P\left(y_{i, j}=1 \mid X\right)=F(X \beta)=\frac{e^{X \beta}}{1+e^{X \beta}}$

where $X \beta$ denote $\beta_{0}+I_{i, j} \beta_{1}+H_{j} \beta_{2}$.

In Table 6 , we summarize the characteristics of higher education students between the ages of 18 and 22. These factors are categorized into three groups: demographic factors, parents' education, and income-related factors. For each variable, we compare the mean value of the higher education participants with the non-participants. The latter can be further decomposed into those having completed high school and those who have not.

Table 6. Socio-economic factors and higher education access

\begin{tabular}{lllll}
\hline & $\begin{array}{l}\text { Higher education } \\
\text { students }\end{array}$ & Non-students & & \\
\hline & & $\begin{array}{l}\text { Finished high } \\
\text { school }\end{array}$ & $\begin{array}{l}\text { No high } \\
\text { school } \\
\text { degree }\end{array}$ & $\begin{array}{l}\text { All non- } \\
\text { students }\end{array}$ \\
Demographic and geographic characteristics & & & & \\
Urban (percent) & 41.3 & 27.1 & 23.1 & 24.5 \\
Female (percent) & 59.6 & 52.7 & 43.3 & 46.6 \\
\hline
\end{tabular}




\begin{tabular}{|c|c|c|c|c|}
\hline Ethnic minority (percent) & 5.1 & 18.5 & 31.3 & 26.8 \\
\hline Head's age (percent) & 50.6 & 50.6 & 49.0 & 49.6 \\
\hline Household size (percent) & 4.3 & 4.5 & 4.8 & 4.7 \\
\hline Proportion of children (percent) & 11.5 & 12.2 & 15.3 & 14.2 \\
\hline Red River Dental (percent) & 29.5 & 27.8 & 12.2 & 17.7 \\
\hline Northern Midland and Mountains (percent) & 9.1 & 18.6 & 19.9 & 19.4 \\
\hline North Central and Coastal Central (percent) & 24.2 & 25.5 & 20.9 & 22.5 \\
\hline Central Highlands (percent) & 7.3 & 4.0 & 9.9 & 7.8 \\
\hline South East (percent) & 17.2 & 13.7 & 17.4 & 16.1 \\
\hline Mekong River Delta (percent) & 12.8 & 10.3 & 19.8 & 16.5 \\
\hline \multicolumn{5}{|l|}{ Education characteristics } \\
\hline Father-Primary or lower (percent) & 21.9 & 39.4 & 54.4 & 49.1 \\
\hline Father- Lower secondary (percent) & 35.7 & 42.0 & 27.0 & 32.3 \\
\hline Father- High school (percent) & 26.5 & 14.6 & 7.7 & 10.1 \\
\hline Father- Junior college (percent) & 2.5 & 0.2 & 0.3 & 0.3 \\
\hline Father-University (percent) & 12.6 & 1.9 & 1.6 & 1.7 \\
\hline Mother-Primary or lower (percent) & 30.7 & 44.5 & 54.3 & 50.8 \\
\hline Mother- Lower secondary (percent) & 33.8 & 38.1 & 21.5 & 27.4 \\
\hline Mother- High school (percent) & 22.3 & 11.2 & 5.3 & 7.4 \\
\hline Mother- Junior college (percent) & 2.2 & 1.0 & 0.7 & 0.8 \\
\hline Mother-University (percent) & 8.9 & 0.9 & 0.7 & 0.8 \\
\hline $\begin{array}{l}\text { At least a parent finished high school or } \\
\text { above (percent) }\end{array}$ & 54.9 & 34.2 & 24.4 & 27.8 \\
\hline $\begin{array}{l}\text { Both parents finished high school or above } \\
\text { (percent) }\end{array}$ & 25.2 & 6.9 & 3.6 & 4.8 \\
\hline $\begin{array}{l}\text { At least a parent finished higher education } \\
\text { (percent) }\end{array}$ & 27.7 & 16.8 & 15.7 & 16.1 \\
\hline $\begin{array}{l}\text { Both parents finished higher education } \\
\text { (percent) } \\
\text { Economic and livelihood conditions }\end{array}$ & 7.1 & 1.0 & 0.6 & 0.7 \\
\hline $\begin{array}{l}\text { Annual expenditure per capita (thousand } \\
\text { VND) }\end{array}$ & 50,162 & 32,630 & 25,068 & 27,737 \\
\hline Quintile 1 (percent) & 3.0 & 17.3 & 34.5 & 28.4 \\
\hline Quintile 2 (percent) & 8.7 & 22.0 & 20.1 & 20.7 \\
\hline Quintile 3 (percent) & 20.3 & 23.3 & 21.8 & 22.4 \\
\hline Quintile 4 (percent) & 30.5 & 20.0 & 14.2 & 16.2 \\
\hline Quintile 5 (percent) & 37.4 & 17.4 & 9.4 & 12.2 \\
\hline In the poor list in 2016 (percent) & 2.8 & 6.7 & 17.8 & 13.9 \\
\hline Head- wage earner (percent) & 44.7 & 40.9 & 41.4 & 41.3 \\
\hline Head- agriculture (percent) & 48.3 & 57.4 & 62.0 & 60.4 \\
\hline Head- non-agriculture business (percent) & 32.5 & 23.5 & 17.3 & 19.5 \\
\hline Observations & 798 & 606 & 1166 & 1772 \\
\hline
\end{tabular}

Note: Parents' education data are for only individuals who are sons or daughters of a household head. 
Table 6 shows that there are noticeable differences between the students and the two groups of non-students. Compared to the nonstudents, the students in HEIs often live in urban areas, in households that are smaller and have a smaller proportion of children. On average, 41.3percent of students live in urban areas, while 24.5 percent of non-students live in urban areas. The average household size is 4.3 persons in the students' households, but 4.7 persons in the non-students' households. Female participation in higher education is higher than male as about 60 percent of higher education students are female, while females account for only 46.6percent of people aged 1822 who neither finish high school nor go to college.

Parental education seems to have a strong correlation with their children's probability of participating in higher education. Among the group of higher education students, 26.5percent have a father who completed high school and 12.6 percent have a father who completed bachelor degree or above. In contrast, only 10.1 percent of non-students have a father who completed high school and 1.7 percent have a father who completed bachelor degree or above. Likewise, 27.7 percent of students have at least a parent with a bachelor degree or above. The corresponding proportion in non-students is only 16.1 percent.
Furthermore, better-off households have much higher participation rates than the poorer ones. About 37.4 percent of students belong to the richest income quintile, and only 3 percent belong to the poorest quintile. This is a sharp contrast to the non-students as only 12.2 percent of non-students belong to the richest quintile, and 28.4 percent belong to the poorest quintile. On average, expenditure per capita of students is 81percent higher than that of nonstudents. Furthermore, only 3 percent of the students belong to households classified by the Government as poor while the corresponding number of the non-students is 13.9 percent.

Table 7 presents results from the logistic regression. The dependent variable is a binary variable which has a value of one if the person is enrolled in a higher educational institution in 2016 and has a zero value otherwise. Model 1 is run for every person aged 18-22. There are two variants of this model: the first conditional on a person completing high school (Model 1A) and the second unconditional, i.e. applying to all people aged 18-22 (Model 1B). Therefore, Model 1A compares students with all nonstudents who have completed high schools (and aged 18-22). Model 1B compares students with all non-students in the same age group including those who have not completed high schools. Each variant is run with sampling weights.

Table 7. Socio-economic factors and higher education access

\begin{tabular}{lllllll}
\hline \multirow{2}{*}{$\begin{array}{l}\text { Dependent variable: } \\
\text { attending higher education }\end{array}$} & Age 18-22 & \multicolumn{3}{c}{ Age 18-22, finished high school } \\
\cline { 2 - 7 } & Coeff. & se & $\begin{array}{l}\text { Marginal } \\
\text { Effect }\end{array}$ & Coeff. & se & $\begin{array}{l}\text { Marginal } \\
\text { Effect }\end{array}$ \\
\hline Age & $8.914^{* * *}$ & $(1.406)$ & 1.393 & $6.291^{* * *}$ & $(1.664)$ & 1.206 \\
Age squared & $-0.225^{* * *}$ & $(0.035)$ & -0.035 & $-0.161^{* * *}$ & $(0.042)$ & -0.031 \\
Female & $0.616^{* * *}$ & $(0.114)$ & 0.096 & $0.324^{* *}$ & $(0.138)$ & 0.062 \\
Head- Primary or lower & $-0.349^{* * *}$ & $(0.134)$ & -0.054 & -0.199 & $(0.165)$ & -0.038 \\
Head- High school & $0.717^{* * *}$ & $(0.163)$ & 0.112 & $0.554^{* * *}$ & $(0.190)$ & 0.106 \\
Head- Junior college & $0.850^{*}$ & $(0.507)$ & 0.133 & 0.393 & $(0.698)$ & 0.075 \\
Head- University & $1.340^{* * * *}$ & $(0.333)$ & 0.209 & $1.743 * * *$ & $(0.488)$ & 0.334 \\
Spouse- Primary or lower & -0.100 & $(0.136)$ & -0.016 & -0.192 & $(0.170)$ & -0.037 \\
Spouse- High school & 0.279 & $(0.187)$ & 0.044 & 0.356 & $(0.220)$ & 0.068 \\
Spouse- Junior college & 0.232 & $(0.516)$ & 0.036 & 0.626 & $(0.711)$ & 0.120 \\
\hline
\end{tabular}




\begin{tabular}{|c|c|c|c|c|c|c|}
\hline Spouse- University & $1.369 * * *$ & $(0.388)$ & 0.214 & $0.989^{*}$ & $(0.509)$ & 0.190 \\
\hline Head is female & -0.105 & $(0.153)$ & -0.016 & -0.026 & $(0.194)$ & -0.005 \\
\hline Head's age & $0.013 *$ & $(0.007)$ & 0.002 & 0.005 & $(0.008)$ & 0.001 \\
\hline Household size & -0.008 & $(0.051)$ & -0.001 & 0.094 & $(0.063)$ & 0.018 \\
\hline Head- wage earner & 0.192 & $(0.137)$ & 0.030 & 0.095 & $(0.168)$ & 0.018 \\
\hline $\begin{array}{l}\text { Head- agriculture } \\
\text { Head- non-agriculture }\end{array}$ & $0.567 * * *$ & $(0.140)$ & 0.089 & $0.469 * * *$ & $(0.167)$ & 0.090 \\
\hline business & $0.457 * * *$ & $(0.153)$ & 0.071 & $0.319^{*}$ & $(0.181)$ & 0.061 \\
\hline Child proportion & 0.625 & $(0.463)$ & 0.098 & 0.486 & $(0.565)$ & 0.093 \\
\hline Ethnic minority & $-0.672 * * *$ & $(0.242)$ & -0.105 & $-0.509^{*}$ & $(0.263)$ & -0.098 \\
\hline Urban & 0.074 & $(0.141)$ & 0.012 & -0.000 & $(0.176)$ & 0.000 \\
\hline $\begin{array}{l}\text { Red River Delta } \\
\text { Northern Midland and }\end{array}$ & -0.263 & $(0.165)$ & -0.041 & $-0.467 * *$ & $(0.189)$ & -0.090 \\
\hline Mountains & -0.302 & $(0.206)$ & -0.047 & $-0.484 * *$ & $(0.235)$ & -0.093 \\
\hline Central Highlands & 0.082 & $(0.233)$ & 0.013 & 0.293 & $(0.307)$ & 0.056 \\
\hline South East & $-0.452 * *$ & $(0.200)$ & -0.071 & -0.251 & $(0.253)$ & -0.048 \\
\hline Mekong River Delta & $-0.315^{*}$ & $(0.175)$ & -0.049 & 0.320 & $(0.230)$ & 0.061 \\
\hline Quintile 1 & $-1.769 * * *$ & $(0.272)$ & -0.276 & $-1.499 * * *$ & $(0.303)$ & -0.287 \\
\hline Quintile 2 & $-0.599 * * *$ & $(0.178)$ & -0.094 & $-0.778 * * *$ & $(0.213)$ & -0.149 \\
\hline Quintile 4 & $0.656^{* * *}$ & $(0.148)$ & 0.102 & $0.586 * * *$ & $(0.183)$ & 0.112 \\
\hline Quintile 5 & $0.972 * * *$ & $(0.165)$ & 0.152 & $0.709 * * *$ & $(0.208)$ & 0.136 \\
\hline Constant & $-90.03 * * *$ & (14.06) & & $-62.309 * * *$ & (16.62) & \\
\hline Pseudo R2 & 0.2524 & & & 0.1768 & & \\
\hline $\begin{array}{l}\text { Observations } \\
\text { Robust standard errors in } \\
\text { parentheses } \\
* * * \mathrm{p}<0.01, * * \mathrm{p}<0.05, * \\
\mathrm{p}<0.1\end{array}$ & 2,570 & & & 1,356 & & \\
\hline
\end{tabular}

Source: Author's estimates from VHLSS2016.

Omitted category: Head's lower secondary school level, spouse's lower secondary school level; North Central and Central Coast; Quintile 3.

Table 7 shows that female youths are more likely to attend university than male youth, consistent with results in Table 6. Among the determinants of higher education access, both head of household and head of household's spouse's education levels have strong impacts. Youth living in households whose heads have high school degrees or tertiary decrees are more likely to go to colleges and universities. Coefficients for head's education at both junior college and bachelor level are higher than those at high school. Therefore, children living in households whose heads or finish junior college and bachelor level are more likely to enroll in tertiary institutions than those living in households whose heads only finish high school. In particular, the marginal effect of "head- university" is calculated to be 0.209 in Model 1A, implying that if a household head has a bachelor degree or above, the probability of a youth in that household enrolling in university is 20.9 percent higher than one living in a household with lesser head's education level. The head spouse's educational level is highly significant at university level, but not in the other levels.

The ethnic minority dummy variable is significant and negative, implying more 
difficulty for ethnic minority youth. Other things being equal, the probability of a youth from an ethnic minority household entering university or college is 10.5 percent lower than her peer from the Kinh/Hoa group (for Model 1A).

Interestingly, "urban" variable is not significant, indicating that the urban residents seem not have more advantages than rural ones in college enrolment. Household size, child proportion and household head's age and head's gender have little or none significant impacts on the tertiary enrolment. However, head's occupation has significant impacts. Household with heads working in agriculture or in non-agricultural business have higher chance of sending kids to higher education.

Household's economic status has very important impact on the chance of attending college. In Model 1A, the probability of attending college of a youth coming from the poorest quintile is 28 percent less than that from the middle quintile. In contrast, this probability is 15 percent higher among those coming from the richest quintile. Thus, this result shows the large inequality in enrolment due to income gap.

This can be further demonstrated by a nonparametric kernel regression in Figure 5 (below) run on all people aged 18-22 who had finished high school. The figure shows that, as the expenditure per capita increases, the probability of attending college also increases. The slope of the curve is quite steep, implying that income is a very important determinant for access to higher education.

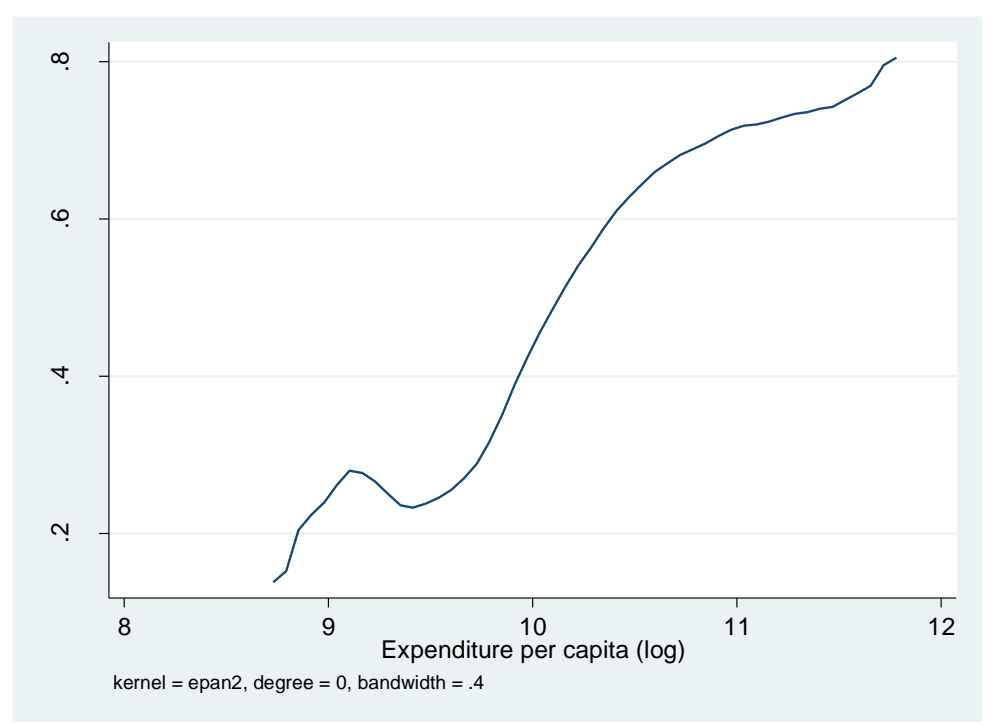

Figure 5. Probability of attending college/university after high school, persons aged 18-22.

Source: Author's estimates from VHLSS2016.

Table 7 shows that head's education and head spouse's education have significant impact on a person's access to higher education. Yet, it is still unclear from Table 7 the particular roles of father's and mother's education in determining a person's access to higher education. In order to examine that, we use a sub-group of the sample including all individuals at the age range from 18 to 22 years who are sons or daughters of the household's head. As we already know the gender of the household's head as well as the education levels of both household heads and head's spouse, it is possible to infer father's and mother's 
education levels of these individuals. We run a logit regression similar to the one in Table 7 but with father's and mother's education levels in places of household head's and head spouse's education levels. The results are summarized in Table 8 .

Table 8. Logit regression model with father and mother's education

\begin{tabular}{|c|c|c|c|c|c|c|}
\hline \multirow{2}{*}{$\begin{array}{l}\text { Dependent variable: attending } \\
\text { higher education }\end{array}$} & \multicolumn{3}{|l|}{ Age $18-22$} & \multicolumn{3}{|c|}{ Age 18-22, finished high school } \\
\hline & Coeff. & se & Marginal effect & Coeff. & se & $\begin{array}{l}\text { Marginal } \\
\text { effect }\end{array}$ \\
\hline Age & $10.00 * * *$ & $(1.536)$ & 1.562 & $1.271 * * *$ & $(0.343)$ & 1.271 \\
\hline Age squared & $-0.252 * * *$ & $(0.038)$ & -0.039 & $-0.033^{* * *}$ & $(0.009)$ & -0.033 \\
\hline Female & $0.540 * * *$ & $(0.124)$ & 0.084 & $0.047 *$ & $(0.028)$ & 0.047 \\
\hline Father- Primary or lower & $-0.397 * * *$ & $(0.150)$ & -0.062 & $-0.062 *$ & $(0.035)$ & -0.062 \\
\hline Father - High school & $0.394 * *$ & $(0.170)$ & 0.062 & $0.069 *$ & $(0.038)$ & 0.069 \\
\hline Father - Junior college & $1.315^{* *}$ & $(0.585)$ & 0.205 & 0.148 & $(0.202)$ & 0.148 \\
\hline Father - University & $1.126 * * *$ & $(0.350)$ & 0.176 & $0.227 * * *$ & $(0.088)$ & 0.227 \\
\hline Mother- Primary or lower & -0.183 & $(0.149)$ & -0.029 & -0.018 & $(0.035)$ & -0.018 \\
\hline Mother - High school & $0.509 * * *$ & $(0.195)$ & 0.079 & $0.100 * *$ & $(0.044)$ & 0.100 \\
\hline Mother - Junior college & -0.063 & $(0.508)$ & -0.010 & 0.010 & $(0.110)$ & 0.010 \\
\hline Mother - University & $1.281 * * *$ & $(0.406)$ & 0.200 & $0.257 * *$ & $(0.118)$ & 0.257 \\
\hline Head is female & 0.024 & $(0.211)$ & 0.004 & 0.016 & $(0.053)$ & 0.016 \\
\hline Head's age & $0.016^{*}$ & $(0.009)$ & 0.003 & 0.001 & $(0.002)$ & 0.001 \\
\hline Household size & $-0.104 *$ & $(0.057)$ & -0.016 & 0.007 & $(0.014)$ & 0.007 \\
\hline Head- wage earner & $0.359 * *$ & $(0.145)$ & 0.056 & 0.036 & $(0.034)$ & 0.036 \\
\hline Head- agriculture & $0.642 * * *$ & $(0.154)$ & 0.100 & $0.100 * * *$ & $(0.034)$ & 0.100 \\
\hline Head- non-agriculture business & $0.623 * * *$ & $(0.162)$ & 0.097 & $0.076^{* *}$ & $(0.037)$ & 0.076 \\
\hline Child proportion & $0.906^{*}$ & $(0.530)$ & 0.142 & 0.124 & $(0.121)$ & 0.124 \\
\hline Ethnic minority & $-0.651 * *$ & $(0.259)$ & -0.102 & -0.081 & $(0.053)$ & -0.081 \\
\hline Urban & 0.153 & $(0.156)$ & 0.024 & 0.031 & $(0.037)$ & 0.031 \\
\hline Red River Delta & -0.165 & $(0.178)$ & -0.026 & $-0.069 *$ & $(0.039)$ & -0.069 \\
\hline Northern Midland and Mountains & -0.222 & $(0.222)$ & -0.035 & $-0.083^{*}$ & $(0.049)$ & -0.083 \\
\hline Central Highlands & 0.178 & $(0.245)$ & 0.028 & 0.057 & $(0.060)$ & 0.057 \\
\hline South East & $-0.465 * *$ & $(0.228)$ & -0.073 & -0.063 & $(0.055)$ & -0.063 \\
\hline Mekong River Delta & -0.193 & $(0.189)$ & -0.030 & 0.066 & $(0.047)$ & 0.066 \\
\hline Quintile 1 & $-1.697 * * *$ & $(0.282)$ & -0.265 & $-0.288 * * *$ & $(0.058)$ & -0.288 \\
\hline Quintile 2 & $-0.593 * * *$ & (0.194) & -0.093 & $-0.135^{* * *}$ & $(0.043)$ & -0.135 \\
\hline Quintile 4 & $0.640 * * *$ & $(0.161)$ & 0.100 & $0.096 * *$ & $(0.037)$ & 0.096 \\
\hline Quintile 5 & $0.825 * * *$ & $(0.181)$ & 0.129 & $0.117 * * *$ & $(0.043)$ & 0.117 \\
\hline Constant & $-100.7 * * *$ & $(15.352)$ & & & & \\
\hline Pseudo R2 & 0.262 & & & 0.1782 & & \\
\hline Observations & 2,166 & & & 1,162 & & \\
\hline
\end{tabular}

Source: Author's estimates from VHLSS2016.

Table 8 shows that both father and mother's education levels at high school and bachelor degree have a positive impact on the enrolment to tertiary schools. The "university or above" 
coefficient is much higher than the 'high school' coefficient, indicating that the ones whose parents have tertiary degrees are much more likely to go to colleges and universities than those whose parents only have high school degrees. On the other hand, if a father or a mother only has primary schooling or no formal education, there is smaller probability that the child will go to college and university.

Comparing between the coefficients and the statistical significance of father's and mother's education, it appears that mother's education has a relatively higher effect than father's education on children's enrolment.

\section{Concluding remarks}

In this research paper, we review the current higher education system in Vietnam as well as analyze inequality in access of tertiary education, using a number of individual and household characteristics from different data sources. Our findings show that improvements of social and economic conditions of the country resulted from Doi Moi have obviously facilitated and developed the education system in general and tertiary education system in particular. However, there have some groups lagged behind the overall progress, especially the low-income people and the ethnic minority people. Yet, females seem have advantage over males at higher education enrolment. It may indicate that there is little gender barrier to women in getting a place at universities. Many men, however, may decide to enter the labor market earlier than women or to take vocational training

Using a logistic regression to determine the factors influencing tertiary education enrolment, we find that income and ethnicity are strong predictors for enrolment. Both father's and mother's education have strongly influence on children's enrolment at tertiary education, especially if a parent completed tertiary degrees.
As such, our paper suggested that the government pay more attention to disadvantaged groups by promoting economic growth in their localities, facilitating education environment, as well as revising student loan policies to finance education costs; all in order to improve access to tertiary education. It is hoped that after getting tertiary education, they will in turn help promote growth and development of their provinces through higher quality human resources.

\section{References}

[1] Crawford, M. and C. Tran (2015). "Vietnamese Higher Education: Characteristics and Challenges". Working paper for the World Bank.

[2] Linh, V.H., G. T. Long and L. V. Thuy (2010). "Equity and Access to Tertiary Education: The Case of Vietnam", unpublished.

[3] Hayden, M. and P. Ly (2015), "Higher Education Access and Inclusion: Lessons from Vietnam," in Teranishi, R et. al. (ed.s). Mitigating Inequality: Higher Education Research, Policy, and Practice in an Era of Massification and Stratification (Advances in Education in Diverse Communities: Research, Policy and Praxis, Volume 11) Emerald Group Publishing Limited, pp.19 - 33.

[4] World Bank (2008). Vietnam: Higher Education and Skills for Growth

[5] Ngo, Doan Dai (2006). "Vietnam." in Higher Education in South-East Asia, Asia-Pacific Programme of Educational Innovation for Development, United Nations Educational, Scientific and Cultural Organization. Bangkok: UNESCO Bangkok, 2006, 219-250.

[6] Murakami, Yuki; Blom, Andreas. 2008. Accessibility and Affordability of Tertiary Education in Brazil, Colombia, Mexico and Peru within a Global Context. Policy Research Working Paper; No. 4517. World Bank, Washington, DC. (c) World Bank. https://openknowledge.worldbank.org/handle/109 86/6427

[7] Usher, A., Cervenan, A., (2005). "Global Higher Education Rankings 2005." Educational Policy Institute, Toronto, ON.

[8] Greene, W (2002). Econometric Analysis, 5th Edition, Prentice Hall. 


\title{
Phân tích sự tiếp cận và tính công bằng trong hệ thống giáo dục đại học ở Việt Nam
}

\author{
Vũ Hoàng Linh ${ }^{1}$, Nguyễn Thùy Anh ${ }^{2}$ \\ ${ }^{1}$ Trương Đại học Việt Nhật- ĐHQGHN, Lưu Hũu Phước, Nam Tù Liêm, Hà Nội, Việt Nam \\ ${ }^{2}$ Truờng Đại học Kinh tế, ĐHQGHN, 144 Xuân Thủy, Cầu Giáy, Hà Nội, Việt Nam
}

Tóm tắt: Hệ thống giáo dục đại học ở Việt Nam được mở rộng nhanh chóng trong hai thập kỷ qua. Tuy nhiên, sự công bằng trong tiếp cận giáo dục đại học hiện nay chưa được đánh giá đầy đủ. Bài viết này là một nỗ lực để xem xét hệ thống giáo dục đại học hiện tại của Việt Nam xét trên các khía cạnh về sự tiếp cận và tính công bằng. Bài viết sử dụng mô hình hồi quy logistic và dữ liệu từ Khảo sát mức sống hộ gia đình Việt Nam 2016 để đánh giá các yếu tố giải thích cho việc đi học Đại học ở Việt Nam. Các kết quả cho thấy việc tồn tại sự chênh lệch lớn trong sự tiếp cận giữa người giàu và người nghèo, và giữa nhóm người Kinh/Hoa và nhóm các dân tộc thiểu số khác ở Việt Nam. Do vậu, các chính sách công để hỗ trợ các nhóm thiệt thòi tiếp cận với giáo dục đại học là cần thiết.

Tù khóa: Giáo dục đại học, tiếp cận, công bằng. 